\title{
MOTIVASI BERPRESTASI: KONSEP DIRI, KECERDASAN EMOSIONAL DAN EFIKASI DIRI
}

\author{
Podensiana Bangung \\ e-mail: podensiana@gmail.com \\ Lilik Sri Hariani \\ e-mail: liliksrihariani@unikama.ac.id \\ Walipah \\ e-mail:walipah@unikama.ac.id
}

(Program Studi Pendidikan Ekonomi, Fakultas Ekonomika dan Bisnis, Universitas Kanjuruhan, Malang)

\begin{abstract}
ABSTRAK: Motivasi berprestasi didorong oleh keinginan individu untuk melakukan sesuatu yang berharga atau penting demi tercapainya suatu target yang telah ditetapkannya. Motivasi berprestasi juga dapat dikatakan sebagai keinginan yang dimiliki seseorang untuk mengatasi hambatan atau mencari solusi untuk menyelesaikan suatu masalah dengan penuh tanggung jawab dan ketelitian berdasarkan standart yang ditetapkan oleh dirinya sendiri untuk mencapai suatu kesuksesan. Penelitian ini bertujuan untuk mengetahui pengaruh konsep diri, kecerdasan emosional dan efikasi diri terhadap motivasi berprestasi mahasiswa pendidikan ekonomi Universitas Kanjutuhan Malang baik secara simultan maupun parsial. Jenis penelitian ini termasuk penelitian ex-post-facto menggunakan metode pendekatan kuantitatif. Populasi dalam penelitian ini adalah mahasiswa pendidikan ekonomi Universitas Kanjuruhan Malang dengan jumlah 87 respinden. Penelitian ini adalah penelitian populasi karena semua anggita populasi dijadikan sampel. Teknik pengumpulan data dalam penelitian ini menggunakan kuesioner. Hasil penelitian ini menunjukkan bahwa terdapat pengaruh positif dan signifikan secara simultan dan parsial antara variabel konsep diri, kecerdasan emosional dan efikasi diri terhadap motivasi berprestasi mahasiswa pendidikan ekonomi UniversitasKanjuruhan Malang.
\end{abstract}

Kata kunci : Konsep, emosional, efikasi, motivasi, prestasi

Abstrack: Achievement motivation is driven by the desire of individuals to do something valuable or important for the achievement of a predetermined target. Achievement motivation can also be said as a desire that someone has to overcome obstacles or find solutions to solve a problem with full responsibility and accuracy based on standards set by themselves to achieve a success. This study aims to determine the effect of self-concept, emotional intelligence and self-efficacy on the achievement motivation of economic education students at the University of Kontinuhan Malang both simultaneously and partially. This type of research includes ex-post facto research using quantitative approaches. The population in this study were students of economic education at Kanjuruhan University Malang with a total of 87 respondents. This study is a population study because all population members are sampled. Data collection techniques in this study used a questionnaire. The results of this study indicate that there is a positive and significant effect simultaneously and partially 
between the variables of self-concept, emotional intelligence and self-efficacy on the achievement motivation of economic education students at the University of Malang Malang.

Keywords : Concept, emotional, efficacy, motivation, achievement.

\section{PENDAHULUAN}

Keberhasilan seseorang dalam dunia pendidikan selalu dikaitkan dengan prestasi yang dicapainya. Bagusnya prestasi yang diperoleh tidak terlepas bagaimana individu memotivasi dirinya. Seseorang yang memiliki motivasi berprestasi yang tinggi akan selalu berusaha untuk mengerjakan suatu tugas dengan sebaik mungkin demi tercapainya target yang telah ditetapkan oleh dirinya sendiri. Motivasi berprestasi didorong oleh keinginan individu untuk melakukan sesuatu yang berharga atau penting demi tercapainya suatu target yang telah ditetapkannya. Motivasi berprestasi juga dapat dikatakan sebagai keinginan yang dimiliki seseorang untuk mengatasi hambatan atau mencari solusi untuk menyelesaikan suatu masalah dengan penuh tanggung jawab dan ketelitian berdasarkan standart yang ditetapkan oleh dirinya sendiri untuk mencapai suatu kesuksesan. Motivasi berprestasi dapat dijadikan sebagai standar prestasi yang digunakan oleh mahasiswa untuk menilai setiap kegiatan yang telah dilakukannya. Selain itu motivasi berprestasi juga suatu hal yang sangat penting dalam menentukan keberhasilan individu mengerjakan sesuatu yang sulit. Mahasiswa yang menginginkan prestasi akan selalu berusaha melakukan suatu pekerjaan dengan sepenuh hati dan teliti serta selalu menilai atau mengevaluasi setiap kegiatanya apakah sudah mencapai target yang ditetapkan ataukah belum (McClelland, 2010:43).

Motivasi berprestasi setiap individu tidaklah sama. Kenyataannya yaitu motivasi berprestasi pada mahasiswa Pendidikan Ekonomi Universitas Kanjuruhan Malang. Berdasarkan hasil pengamatan yang dilakukan oleh peneliti, mahasiswa pendidikan ekonomi ada yang motivasi berprestasinya tinggi dan ada pula yang motivasi berprestasinya rendah. Mahasiswa yang motivasi berprestasinya tinggi nampak jelas terlihat ketika mahasiswa tersebut selalu rajin datang kuliah, tidak pernah datang kampus terlambat, mahasiswa yang selalu mengikuti perkuliahan dengan tenang, mahasiswa yang selalu mengerjakan tugas dengan penuh teliti, percaya pada kemampuan diri sendiri dan mengumpulkannya tepat pada waktu yang telah ditentukan serta mahasiswa yang tidak suka menyontek. Sebaliknya mahasiswa yang motivasi berprestasi rendah sangat nampak terlihat ketika mahasiswa tersebut jarang mengikuti perkuliahan, selalu datang terlambat, mengerjakan tugas asal mengerjakan dan mahasiswa yang tidak percaya pada kemampuan dirinya sendiri. Motivasi berprestasi dapat juga dijadikan tolak ukur bagi seorang mahasiswa untuk mencapai tujuan yang telah ditetapkannya. Mahasiswa yang memiliki motivasi berprestasi tinggi akan selalu berusaha mengerjakan sesuatu hal yang sudah ditargetkanya dengan sebaik mungkin dan sempurna serta tepat pada waktunya dibandingkan dengan mahasiswa yang motivasi berprestasinya rendah. Namun tinggi atau rendahnya motivasi berprestasi seseorang dapat dipengaruhi oleh beberapa factor. Manafi, Mohammadi \&Hejazi (2015), mengemukakan bahwa faktor-faktor yang mempengaruhi motivasi berprestasi antara lain usaha, berorientasi pada tujuan, ketekunan, keahlian dan kemampuan. Dalam penelitian ini, peneliti ingin melihat apakah faktor konsep diri, kecerdasan emosional dan efikasi diri dapat mempengaruhi motivasi berprestasi.

Konsep diri menjadi salah satu aspek penting dalam kehidupan seseorang karena konsep diri menunjukan bagaimana pandangan seseorang tentang dirinya sendiri. Konsep diri seorang mahasiswa dapat mempengaruhi motivasi atau keinginannya untuk berprestasi atau mencapai target yang sudah ditetapkannya (Ghufron dan Risnawati 2011). Selain konsep diri, kecerdasan emosional juga sangat penting bagi mahasiswa ketika mahasiswa tersebut sedang mengalami suatu tekanan tertentu. Seorang mahasiswa yang memiliki kecerdasan emosional maka ia akan mampu 
mengendalikan dirinya dikala ada persoalan tertentu, mampu menahan emosi dan mampu memotivasi dirinya yang akan meningkatkan kesadarannya untuk belajar sehingga dapat memperoleh prestasi belajar yang memuaskan (Goleman dalam Imam Musbikin, 2013: 85). Efikasi diri juga merupakan suatu hal yang sangat penting dalam meningkatkan motivasi berprestasi seorang mahasiswa. Mahasiswa yang memiliki efikasi diri akan selalu mampu menggunakan potensi yang dimilikinya secara optimal. Oleh karena itu efikasi diri sangat penting untuk dimiliki oleh setiap mahasiswa karena dengan adanya efikasi diri mahasiswa dapat memiliki keyakinan yang kuat untuk kemampuan yang dimiliknya serta memiliki dorongan untuk berprestasi sehingga dapat mencapai tujuan yang dinginkannya (Bandura dalam M. Nur Ghufron \& Rini Risnawati S, 2010: 73). Adapun tujuan dalam penelitian ini sesuai dengan latar belakang dan rumusan masalah adalah untuk mengetahui apakah ada pengaruh baik secara simultan maupun secara parsial antar variabel konsep diri, kecerdasan emosional dan efikasi diri terhadap motivasi berprestasi mahasiiswa pendidikan ekonomi Universitas kanjuruhan Malang. Peneliti mengharapkan dengan adanya penelitian ini diharapkan universitas mampu meningkatakan motivasi berprestasi mahasiswa berdasarkan variabel-variabel yang peneliti jelaskan.

\section{TINJAUAN PUSTAKA}

Motivasi berprestasi adalah dorongan yang adalam diri seseorang untuk melakukan suatu tugas tertentu untuk mencapai kesuksesan (Djaali, 2012107). Motivasi berprestasi seorang mahasiswa dipengaruhi oleh beberapa faktor diantaranya yaitu konsep diri, kecerdasan emosional dan efikasi diri. Konsep diri berkaitan dengan gambaran atau penilaian seorang individu terhadap dirinya sendiri. Konsep diri berkaitan dengan gambaran atau penilaian seorang individu terhadap dirinya sendiri. Konsep diri sebagai pandangan seseorang pada dirinya yaitu cara bagaimana ia menilai dirinya sendiri, bagaimana penerimaaanya pada dirinya sendiri sebagaimana yang dialaminya, dipercaya, dan yang sudah dijalankan, baik ditinjau dari segi jasmani, rohani, moral, personal, dan social (Hurlock dalam Gufron, 2011: 13). Apabila seorang mahasiswa menilai dirinya dengan hal-hal positif tentu itu akan mendorong mahasiswa tersebut untuk melakukan suatu tugas untuk mencapai target yang telah ditetapkan. Selain konsep diri, mahasiswa harus memiliki kecerdasan emosional karena kecerdasan emosional berkaitan dengan bagaimana individu mampu menghadapi segala tekanan-tekanan tertentu, mampu mengelola emosinya (Makmum Khairani, 2013). Apabila mahasiswa mampu mengenali perasaannya dan perasaan orang disekitarnya, mampu mengelola emosi dengan baik pada diri sendiri, dan saat berinterkasi dengan orang lain maka mahasiswa tersebut memiliki keinginanan yang bertujuan untuk mendapatkan penerimaan atau menjauhi celaan dari diri sendiri maupun orang lain dan berhubungan dengan kinerjanya dalam situasi yang menerapkan standar keunggulan. Kecerdasan emosional yang baik memberikan dorongan bagi mahasiswa untuk melakukan sesuatu berdasarkan standar yang telah ditetapkannya. Efikasi diri juga yang penting dimiliki oleh setiap mahasiswa karena berkaitan dengan rasa yakin seorang mahasiswa pada kemampuan yang dimilikinya dalam menyelesaikan suatu tugas atau usaha yang perlukan dilakukan dalam mencapai keberhasilan. Efikasi diri yaitu keyakinan atau kepercayaan diri seseorang pada kemampuan yang ia miliki untuk mengerjakan tugas dalam situasi tertentu (Laura A. King 2012: 412). Mahasiswa yang memiliki efikasi diri berarti mahasiswa yang percaya dan yakin seutuhnya pada kemampuan yang ia miliki bahwa sesungguhnya mahasiswa tersebut akan berhasil dalam mencapai target yang sudah ditetapkannya.

Kajian emprik yang digunakan dalam penelitian ini adalah Penelitian yang dilakukan oleh Asep Budi Hartono (2015) pengaruh konsep diri dan efikasi diri terhadap motivasi berprestasi 
(Survei Pada Mahasiswa Pe FKIP Universitas Kuningan). Penelitian ini menunjukan bahwa konsep diri dan efikasi diri masing-masing berpengaruh secara positif dan signifikan terhadap motivasi berprestasi mahasiswa. Penelitian yang dilakukan Wahyu Puji Lestari, dkk (2013) pengaruh self efficacy dan kecerdasan emosi terhadap motivasi berprestasi siswa SMK PGRI 1 Madiun. Penelitian ini menunjukan bahwa self efficacy dan kecerdasan emosi masing-masing berpengaruh secara positif dan signifikan terhadap motivasi berprestasi siswa. Menurut Hidayat (2014) kerangka konsep merupakan Justifikasi ilmiah terhadap topik yang dipilih sesuai dengan identifikasi masalah. Kerangka konsep harus didukung landasan teori yang kuat serta ditunjang oleh informasi yang bersumber pada berbagai laporan ilmiah, hasil penelitian, jurnal penelitian dan lain-lain.

\section{METODE}

Jenis penelitian ini yaitu penelitian expost facto, karena Karena penelitian yang berhubungan dengan variabel yang telah terjadi dan mereka tidak perlu memberikan perlakukan terhadap variabel yang diteliti. Penelitian ini menggunakan pendekatan kuantitatif, karena data diwujudkan dalam bentuk angka dan di analisis menggunakan analisis statistic dibantu dengan menggunakan program SPSS Versi 22.0 for windows. Analisis data merupakan salah satu kegiatan penelitian berupa proses penyusunan dan pengolahan data guna menafsirkan data yang diperoleh. Teknis analisis yang digunakan dalam penelitian ini adalah analisis kuantitatif. Metode ini digunakan untuk mendapatkan data penelitian. Populasi dalam penelitian ini adalah mahasiswa pendidikan ekonomi Universitas Kanjuruhan Malang yang berjumlah 87 mahasiswa. Penelitian ini merupakan penelitian populasi karena semua populasinya dijadikan sampel penelitian. Teknik pengambilan data dalam penelitian ini adalah dengan menggunakan angket. Metode analisis yang digunakan dalam penelitian ini yaitu model regresi linear berganda dan pengujian hipotesis menggunakan analisis uji $F$, uji $t$ dan $\mathrm{R}^{2}$.

\section{HASIL DAN PEMBAHASAN}

Penelitian ini menggunakan tiga variabel bebas yang diduga memiliki pengaruh terhadap motivasi berprestasi mahasiswa pendidikan ekonomi Universitas Kanjuruhan Malang. Deskripsi hasil penelitian yang diperoleh dari pengumpulan data dengan instrumen peneltian skala likert. Pemaparan tersebut meliputi variabel: konsep diri, kecerdasan emosional, efikasi diri, dan motivasi berprestasi mahasiswa pendidikan ekonomi Universitas Kanjuruhan Malang mencakup mean, median, mode, standart deviation, variance, range, skor minimum, skor maximum, dan sum. Berdasarkan hasil penelitian statistic dengan bantuan komputer melalui program SPSS Versi 22.0 for windows diperoleh tabel Anova yang menunjukkan Uji F statistik. Adapun hasil dari uji F pada Tabel Anova disajikan dalam Tabel 1.

Tabel 1. Hasil Uji F (Uji Secara Simultan)

\begin{tabular}{llrrrrr}
\multicolumn{7}{c}{ ANOVA $^{\mathrm{a}}$} \\
\hline Model & & Sum of Squares & $\mathrm{df}$ & Mean Square & F & Sig. \\
\hline \multirow{2}{*}{1} & Regression & 757,365 & 3 & 252,455 & 23,152 &, $000^{\mathrm{b}}$ \\
\cline { 2 - 7 } & Residual & 905,071 & 83 & 10,904 & & \\
\cline { 2 - 7 } & Total & 1662,437 & 86 & & & \\
\hline
\end{tabular}

a. Dependent Variable: Motivasi Berprestasi
b. Predictors: (Constant), Efikasi Diri (X3), Kecerdasaan Emosional (X2), Konsep Diri (X1)

Sumber : Hasil olahan SPSS versi 22.00 for windows 
Berdasarkan Tabel 1 diperoleh nilai $F_{\text {hitung }}$ sebesar 23,152 dengan tingkat signifikan 0 , 000 karena tingkat signifikan lebih kecil dari 0,05 , maka $\mathrm{Ho}_{1}$ ditolak dan $\mathrm{Ha}_{1}$ diterima artinya yaitu: konsep diri, kecerdasan emosional dan efikasi diri, secara simultan berpengaruh signifikan terhadap motivasi berprestasi pada mahasiswa pendidikan ekonomi Universitas Kanjuruhan Malang. Berdasarkan hasil perhitungan statistik dengan bantuan computer melalui program SPSS Versi 22.0 for windows diperoleh tabel coefficients yang menunjukkan uji $\mathrm{t}$ statistik. Uji $\mathrm{t}$ digunakan untuk menguji signifikan pengaruh masing-masing dari variabel independen yang terdiri dari konsep diri, kecerdasan emosional dan efikasi diri dengan variabel dependen yaitu motivasi berprestasi . Hasil uji t pada penelitian ini dapat dilihat pada Tabel 2 berikut ini:

Tabel 2 Hasil Uji t (Uji Signifikan Parsial)

\begin{tabular}{lllll}
\multicolumn{2}{c}{} & \multicolumn{2}{l}{ Coeffients } & Keterangan \\
\hline \multicolumn{2}{l}{ Model } & $\mathrm{T}$ & Sig & \\
\hline \multirow{2}{*}{1} & (constant) & $-1,884$ &, 063 & \\
\cline { 2 - 5 } & $\left(\mathrm{X}_{1}\right)$ & 3,157 &, 002 & Signifikan \\
\cline { 2 - 5 } & $\left(\mathrm{X}_{2}\right)$ & 3,015 &, 003 & Signifikan \\
\cline { 2 - 5 } & $\left(\mathrm{X}_{\mathrm{a}}\right)$ & 4,528 &, 000 & Signifikan \\
\hline
\end{tabular}

Sumbe

a. Dependent Variabel: Motivasi Berprestasi

r

Hasil

olahan SPSS versi 22.00 for windows

Berdasarkan Tabel 2 hipotesa penelitian untuk mengui hipotesa kedua adalah sebagai berikut: berdasrkan hasil analisis diperoleh nilai thitung untuk variabel konsep diri sebesar 3,157 dengan tingkat signifikan 0,002 karena tingkat signifikan lebih kecil dari 0,05 maka variabel konsep diri berpengaruh terhadap variabel motivasi berprestasi mahasiswa pendidikan ekonomi Universitas Kanjuruhan Malang. Artinya ada pengaruh yang signifikan secara parsial antara konsep diri terhadap motivasi berprestasi mahasiswa pendidikan ekonomi Universitas Kanjuruhan Malang. Hipotesa penelitian untuk mengui hipotesa ketiga adalah sebagai berikut: berdasrkan hasil analisis diperoleh nilai thitung untuk variabel kecerdasan emosional sebesar 3,015 dengan tingkat signifikan 0,003 karena tingkat signifikan lebih kecil dari 0,05 maka variabel kecerdasan emosional berpengaruh terhadap variabel motivasi berprestasi mahasiswa pendidikan ekonomi Universitas Kanjuruhan Malang. Artinya ada pengaruh yang signifikan secara parsial antara kecerdasan emosional terhadap motivasi berprestasi mahasiswa pendidikan ekonomi Universitas Kanjuruhan Malang. Hipotesa penelitian untuk menguji hipotesa keempat adalah sebagai berikut: berdasrkan hasil analisis diperoleh nilai thitung untuk variabel efikasi diri sebesar 4,528 dengan tingkat signifikan 0,000 karena tingkat signifikan lebih kecil dari 0,05 maka variabel efikasi diri berpengaruh terhadap variabel motivasi berprestasi mahasiswa pendidikan ekonomi Universitas Kanjuruhan Malang. Artinya ada pengaruh yang signifikan secara parsial antara efikasi diri terhadap motivasi berprestasi mahasiswa pendidikan ekonomi Universitas Kanjuruhan Malang. Berikut in adalah penjelasan dari hasil penelitian yang telah dilakukan oleh peneliti, sebagai berikut:

Pengaruh Konsep Diri, Kecerdasan Emosional, Dan Efikasi Diri Terhadap Motivasi Berprestasi Mahasiswa Pendidikan Ekonomi Universitas Kanjuruhan Malang

Berdasarkan hasil penelitian, untuk mengetahui secara bersama-sama konsep diri, kecerdasan emosional dan efikasi diri terhadap motivasi berprestasi mahasisiwa pendidikan ekonomi Universitas Kanjuruhan Malang. Motivasi berprestasi mahasiswa didukung oleh konsep diri, 
kecerdasan emosional dan efikasi diri yang baik. Ketika konsep diri mahasiswa baik, maka dia juga memiliki suasana hati yang positif, mampu memotivasi dirinya sehingga dia memiliki keyakinan pada kemampuannya untuk melakukan suatu tugas demi tercapainya tujuan yang sudah ditetapkan. Semakin tinggi konsep diri, kecerdasan emosional dan efikasi diri mahasiswa maka semakin tinggi pula motivasi berprestasinya (Junqing Fu 2011\} Putri, Monika, dan Ninawati 2016). Demikian pula sebaliknya semakin rendah konsep diri, kecerdasan emosional dan efikasi diri maka akan semakin rendah pula pula motivasi berprestasinya. Mahasiswa pendidikan ekonomi yang memiliki konsep diri yang baik, kecerdasan emosional yang tinggi dan memiliki efikasi diri tinggi, maka bisa dipastikan mahasiswa tersebut memiliki tingkat motivasi berprestasi yang tinggi. Oleh karena itu, konsep diri, kecerdasan emosional dan efikasi diri secara simultan berpengaruh terhadap motivasi berprestasi mahasiswa pendidikan ekonomi Universitas kanjuruhan malang.

\section{Pengaruh Konsep Diri Terhadap Motivasi Berprestasi Mahasiswa Pendidikan Ekonomi Universitas Kanjuruhan Malang}

Berdasarkan hasil penelitian menunjukan bahwa variabel konsep diri berpengaruh signifikan terhadap motivasi berprestasi mahasiswa pendidikan ekonomi Universitas Kanjuruhan Malang. Konsep diri memiliki peran yang sangat penting dalam meningkatkan motivasi berprestasi mahasiswa pendidikan ekonomi karena konsep diri berkaitan dengan penilaian individu terhadap dirinya sendiri. Setiap mahasiswa diharapkan mampu menilai dirinya sendiri agar mahasiswa dapat memperbaiki diri dan melakukan suatu perubahan dari dirinya untuk mencapai target yang telah ditetapkannya. Mahasiswa yang memiliki konsep diri yang baik, maka tingkat motivasi berprestasinya semakin tinggi dan sebaliknya (Viktor, 2011). Penilaian mahasiswa pendidikan ekonomi pada dirinya sendiri dapat mempengaruhi motivasi atau adanya keinginan dalam dirinya berprestasi atau mencapai target yang sudah ditetapkannya (Putri, Monika, dan Ninawati 2016). Konsep diri dapat dijadikan penentu sikap mahasiswa dalam menjalankan segala aktivitas atau suatu kegiatan. Ketika seorang mahasiswa pendidikan ekonomi mampu menilai dirinya maka ia akan cendrung berusaha dan berpikir akan berhasil, sehingga hal itu dapat dijadikan kekuatan atau dorongan bagi dirinya untuk meningkatkan motivasi berprestasinya. Hasil penelitian ini sejalan dengan penelitian yang dilakukan oleh Eko Sujadi, dkk (2018) terdapat pengaruh yang positif dan signifikan antara konsep diri terhadap motivasi berprestasi mahasiswa di IAIN Kerinci

Pengaruh Kecerdasan Emosional Terhadap Motivasi Berprestasi Mahasiswa Pendidikan Ekonomi Universitas Kanjuruhan Malang

Hasil penelitian menunjukan bahwa variabel kecerdasan emosional berpengaruh signifikan terhadap motivasi berprestasi mahasiswa pendidikan ekonomi Universitas Kanjuruhan Malang. Kecerdasan emosional mendorong mahasiswa pendidikan ekonomi untuk mampu bertahan dalam situasi yang sulit sehingga dapat memperoleh kemajuan pada dirinya. Kecerdasan emosional yang baik memberikan dorongan bagi mahasiswa untuk melakukan sesuatu berdasarkan standar yang telah ditetapkannya. Mahasiswa yang memiliki kecerdasan emosional sangat tinggi maka semakin besar pula tingkat motivasi berprestasinya. Karena dalam mengerjakan segala tugas tidak akan terselesaikan apabila mahasiswa tidak memiliki kecerdasan emosional. Ketika seorang mahasiswa mampu mengelola emosinya maka mahasiswa tersebut akan terus fokus pada target yang ingin dicapainya (V. Teguh Suharto, 2011: 142). Dengan adanya kecerdasan emosional, mahasiswa pendidikan eknomi bisa memahami perasaan mereka sendiri dengan baik dan menanggapi perasaan orang lain dengan bijaksana. Mahasiswa pendidikan ekonomi dengan kecerdasan emosional yang baik berarti ia memiliki kesempatan besar ia untuk berhasil dalam segala tujuan yang sudah ditetapkannya dan memiliki keinginan yang kuat untuk berprestasi. Hasil penelitian ini sejalan dengan penelitian yang dilakukan Toto Suharto (2011) terdapat pengaruh yang positif dan signifikan antara kecerdasan emosional terhadap motivasi berprestasi mahasiswa pendidikan ekonomi. 


\section{Pengaruh Efikasi Diri Terhadap Motivasi Berprestasi Mahasiswa Pendidikan Ekonomi Universitas Kanjuruhan Malang}

Hasil penelitian menunjukan bahwa variabel efikasi diri berpengaruh signifikan terhadap motivasi berprestasi mahasiswa pendidikan ekonomi Universitas Kanjuruhan Malang. Efikasi diri juga memiliki peran yang sangat penting dalam meningkatkan motivasi berprestasi seorang mahasiswa. Karena dengan adanya efikasi diri mahasiswa akan yakin dan percaya sepenuhnya dengan kemampuan yang dimilikinya. Apabila mahasiswa memiliki efikasi diri yang tinggi tentunya dia juga memiliki motivasi berprestasi yang tinggi sehingga dia akan terus terdororng untuk melakukan suatu tugas yang sangat penting dengan percaya pada kemampuan dirinya sendiri (Junqing Fu 2011). Karena pada dasarnya dalam mengerjakan suatu tugas tidak akan terselesaikan dengan baik apabila mahasiswa tidak yakin dengan kemampuan yang dimilikinya. Mahasiswa pendidikan ekonomi dengan efikasi diri selalu berusaha mengerjakan suatu hal dengan penuh keyakinan akan kemampuan yang dimilikinya tanpa bergantung pada orang lain. Efikasi diri menunjukan keyakinan individu pada kemampuannya dalam menyelesaikan suatu tugas yang dapat mencapai targetnya. Mahasiswa pendidikan ekonomi yang memiliki efikasi diri juga berarti mahasiswa yang percaya dan yakin sepenuhnya pada kemampuan yang dimiliki bahwa sesungguhnya mahasiswa tersebut akan berhasil mencapai tujuannya. Semakin tinggi efikasi diri yang dimiliki mahasiswa pendidikan ekonomi semakin tinggi pula keyakinannya pada kemampuan yang dimiliki untuk mencapai targetpun dapat tercapai. Hasil penelitian ini sejalan dengan dilakukan oleh Asep Budi Hartono (2011 terdapat pengaruh yang positif dan signifikan antara efikasi diri terhadap motivasi berprestasi pada mahasiswa Pe FKIP Universitas Kuningan.

\section{KESIMPULAN}

Berdasarkan hasil penelitian yang dilakukan, maka kesimpulannya adalah sebagai berikut: Terdapat pengaruh yang positif dan signifikan secara simultan konsep diri, kecerdasan emosional dan efikasi diri terhadap motivasi berprestasi mahasisiwa pendidikan ekonomi Universitas Kanjuruhan Malang. Terdapat pengaruh yang positif dan signifikan secara parsial konsep diri terhadap motivasi berprestasi mahasisiwa pendidikan ekonomi Universitas Kanjuruhan Malang. Terdapat pengaruh yang positif dan signifikan secara parsial kecerdasan emosional terhadap motivasi berprestasi mahasisiwa pendidikan ekonomi Universitas Kanjuruhan Malang. Terdapat pengaruh yang positif dan signifikan secara parsial efikasi diri terhadap motivasi berprestasi mahasisiwa pendidikan ekonomi Universitas Kanjuruhan Malang.

Bedasarkan kesimpulan di atas, maka saran yang dapat diberikan peneliti yaitu yang pertama bagi peneliti diharapkan peneliti bisa memperbaiki kekurangan-kekurangan yang ada dalam penelitian ini sehingga dapat menambah wawasan tentang motivasi berprestasi. Kedua bagi mahasisiswa penelitian ini digunakan sebagai evaluasi tentang pentingnya konsep diri, kecerdasan emosional dam efikasi diri dalam meningkatkan motivasi berprestasi mahasiswa pendidikan ekonomi Universitas Kanjuruhan Malang. Ketiga bagi peneliti selanjutnya diharapkan dapat menjadi dasar dalam pengembangan penelitian yang dilakukan dimana memiliki kesamaan variabel yaitu konsep diri, kecerdasan emosional dam efikasi diri sebagai variabel bebas dan motivasi berprestasi sebagai variabel terikat. Keempat bagi dapat Universitas kanjuruhan Malangdijadikan sebagai daftar rujukan mahasiswa yang sedang mencari informasi mengenai pengaruh konsep diri, kecerdasan emosional dan efikasi diri terhadap motivasi berprestasi mahasiswa pendidikan ekonomi Universitas Kanjuruhan Malang.

\section{DAFTAR PUSTAKA}

Djaali, H. Prof. Dr. (2013). Psikologi pendidikan. Jakarta: PT. Bumi Aksar. 
Feist, Jess, \&Feist, J Gregory. 2011. Teori kepribadian (Theories of personality). Jakarta Selemba Humanika

Gufron, M. 2011. Teori -Teori Psikologi. Yogyakarta: Ar-ruzz Media.

Goleman, Daniel. (2012). Emotional Intelligence. Jakarta: PT Gramedia Pustaka Utama.

Hurlock, E.B. (2012). Psikologi Perkembangan: Suatu Pendekatan Sepanjang Rentan Kehidupan.Jakarta: Erlangga.

McClelland, D. C. (2010).The Achieving Sosiety. Princeton, New Jersi:Martino Publishing.

Musbikin, Imam. 2013. Mengatasi Kenakalan Siswa Remaja. pekanbaru: Zanafa Publishing.

Makmum Khairani. (2013). Psikologi Belajar. Yogyakarta: Aswaja Presindo

Rakhmat, Jalaludin. 2013. Psikologi Komunikasi. Bandung: PT. Remaja Rosda Karya

Laura A.King. 2012. Psikologi Umum. Sebuah Pandangan Apresiatif. Jakarta: Salemba Humanika

Fu, Junqing. (2011). The Relationships Among Self-Efficacy, Achievement Motivation, and Work Values For Regular Four-Year University Students and Community College Students in China. Disertasi

Manafi, D., Mohammadi, S. H., \& Hejazi, S, Y. (2015) Factor Analysis Of Student's Achievement Motivation Variabels (Case Study: Agricultural Ms. C Student In Tehran University). Internasional Journal Of Advanced Biological And Biomedical Research 134-138

Putri, F, A, Monika, S., \& Ninawati, (2016) Hubungan Konsep Diri Dengan Motivasi Berprestasi Pada Mahasiswa Akselerasi Dan Reguler. Provitae Jurnal Psikologi Pendidikan.

V. Teguh Suharto. 2011. Perbedaan Keefektifan Model pembelajaran Experiential Learning, Sinektik, dan Pengajaran Langsung dalam Pembelajaran Apresiasi Prosa Fiksi Ditinjau dari Kecerdasan Emosional Siswa. Eksperimen pada Sekolah Menengah Pertama di Jawa Timur, 17 (2):130-157.

Viktor, G.T. 2011. Parenting Styles on Children's Self-Concept and Academic Performance In Adama wa State. Thesis. Zaria: Faculty of Education. Ahmadu Bello University, Nigeria 